\title{
Investigation of annealing temperature effect on magnetron sputtered cadmium sulfide thin film properties
}

\author{
E. Akbarnejad $^{1}$ - Z. Ghorannevis ${ }^{2}$ F. Abbasi ${ }^{1} \cdot$ M. Ghoranneviss ${ }^{1}$
}

Received: 11 June 2016/ Accepted: 26 November 2016/Published online: 17 December 2016

(C) The Author(s) 2016. This article is published with open access at Springerlink.com

\begin{abstract}
Cadmium sulfide (CdS) thin films are deposited on the fluorine doped tin oxide coated glass substrate using the radio frequency magnetron sputtering setup. The effects of annealing in air on the structural, morphological, and optical properties of CdS thin film are studied. Optimal annealing temperature is investigated by annealing the $\mathrm{CdS}$ thin film at different annealing temperatures of 300, 400, and $500{ }^{\circ} \mathrm{C}$. Thin films of CdS are characterized by X-ray diffractometer analysis, field emission scanning electron microscopy, atomic force microscopy, UV-Vis-NIR spectrophotometer and four point probe. The as-grown CdS films are found to be polycrystalline in nature with a mixture of cubic and hexagonal phases. By increasing the annealing temperature to $500{ }^{\circ} \mathrm{C}, \mathrm{CdS}$ film showed cubic phase, indicating the phase transition of CdS. It is found from physical characterizations that the heat treatment in air increased the mean grain size, the transmission, and the surface roughness of the CdS thin film, which are desired to the application in solar cells as a window layer material.
\end{abstract}

Keywords RF Sputtering $\cdot$ CdS $\cdot$ Post annealing $\cdot$ Band gap $\cdot$ FESEM

Z. Ghorannevis

ghoranneviszohreh@gmail.com

1 Plasma Physics Research Centre, Islamic Azad University, Science and Research Branch, Tehran, Iran

2 Department of Physics, Karaj Branch, Islamic Azad University, Karaj, Iran

\section{Introduction}

In recent years, extensive research has been done on a preparation and characterization of CdS thin films due to the promising applications in photovoltaic solar cells such as CdTe [1], CZTS [2], and CIGS [3]. CdS is the n-type semiconductor with a direct optical band gap of around $2.45 \mathrm{eV}$, which is used as a window layer in solar cells. In $\mathrm{CdS} / \mathrm{CdTe}$ solar cell, the light is transmitted through the CdS layer to the p-type CdTe absorber layer and the photogenerated electron-hole pairs are divided in the depletion region of the CdS/CdTe hetero junction. CdS in a photovoltaic solar cell does not just act as a window layer, but also play a part in carrier generation due to its high photosensitivity $[4,5]$. Therefore, the physical properties of the $\mathrm{CdS}$ layers can influence the characteristics of $\mathrm{CdS} / \mathrm{CdTe}$ hetero junction interface and consequently, the performance of the cell [6]. Heat treatment is often used to tune the structure and properties of thin films such as CdS. It is because crystalline quality of the film plays an important role in the utilization of the CdS films for solar cell applications and thermal annealing leads to improve the crystalline quality of the films by the removal of strains, which can lead to the phase transition and thereby changing the band gap. Since annealing brings positive as well as negative effects to $\mathrm{CdS}$ physical properties [7, 8], therefore, a better understanding of the impact of the annealed $\mathrm{CdS}$ film on the properties of the CdS/CdTe solar cell is still needed. Polycrystalline $\mathrm{CdS}$ thin films have been prepared by different techniques including vacuum evaporation [9], chemical bath deposition (CBD) [10], electrodeposition [11], sputtering [12], and laser ablation [13].

In this work, CdS thin films are grown by radio frequency (RF) magnetron sputtering set up using $\mathrm{CdS}$ as a target by generating the argon plasma on fluorine doped tin 
oxide (FTO) coated glass. Following the growth procedure, the CdS thin films are annealed by thermal chemical vapor deposition (TCVD) method in an attempt to increase its transmission as a window layer and band gap engineering. The structural, morphological, optical, and electrical properties of the annealed CdS thin films are analyzed by $\mathrm{X}$-ray diffractometer (XRD), atomic force microscopy (AFM), field emission scanning electron microscopy (SEM), spectrophotometer, and four point probe, respectively.

\section{Experimental}

CdS thin films are grown on FTO/glass substrate by RF magnetron sputtering method from the 3 inch CdS target with $99.999 \%$ purity (Kurt J. Lesker Co.). The FTO substrates were ultrasonically cleaned with acetone and ethanol, and dried immediately with pure nitrogen gas to remove surface contamination and achieve good adhesion of layer to substrates [14]. The sputter chamber was evacuated to a high vacuum of $8 \times 10^{-6}$ Torr by the assistance of rotary and turbo pumps. Prior to the sputtering, the CdS target pre-sputtered for $15 \mathrm{~min}$. The working pressure of deposition was set at $2 \times 10^{-2}$ Torr. The distance between the substrate and target was kept at $7 \mathrm{~cm}$ [15]. RF power of $150 \mathrm{Watt}$ used for $30 \mathrm{~min}$ deposition of CdS thin films on FTO substrates. After deposition, the $\mathrm{CdS}$ thin film was placed in a furnace for post annealing at three different temperatures of 300,400 , and $500{ }^{\circ} \mathrm{C}$ in air for $30 \mathrm{~min}$. Structural, morphological, and optical properties of the post annealed CdS/FTO are studied to investigate the effect of the annealing on the physical properties of the CdS thin films. Crystalline structure of the films are studied by XRD using a Stoe XPERT-PRO diffractometer and the X-ray scans are performed using $\mathrm{Cu} \mathrm{K}_{\alpha}$ radiation $\left(\mathrm{Cu} \mathrm{K} \mathrm{K}_{\alpha}=0.154 \mathrm{~nm}\right)$. Optical properties of the films are investigated by UV-VIS-NIR spectrophotometer (Cary 500 Scan). FESEM (Hitachi S4160) and AFM (Solver Next, NT-MD) are used for analyzing morphological properties and measuring the roughness of the samples.

\section{Result and discussion}

Figure 1 shows the XRD pattern of CdS film (as-grown, annealed at 300,400 , and $500{ }^{\circ} \mathrm{C}$ ). All the samples are found to be polycrystalline in nature. It is mentionable that the identification and assignments of the observed diffraction patterns are made using the JCPDS data. The asgrown film and annealed film at $300{ }^{\circ} \mathrm{C}$ show a predominant single peak at $26.56^{\circ}$ and $26.5^{\circ}$, respectively, indicating a strong preferred orientation along the (002) plane

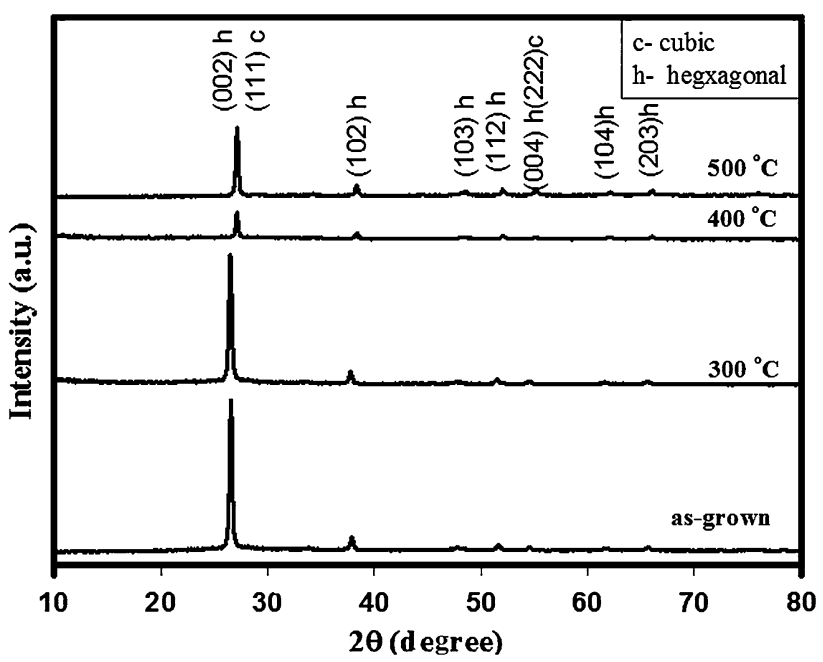

Fig. 1 XRD spectra for the as-grown, annealed at 300, 400, and $500{ }^{\circ} \mathrm{C} \mathrm{CdS}$ samples

of the hexagonal CdS. On the other hand, in case of the $\mathrm{CdS}$ samples annealed at 400 and $500{ }^{\circ} \mathrm{C}$ the peaks shifts to the values of 27.13 and 27.14 (to right), which indicates the (111) reflection of the cubic modification. These observations suggest that by increasing the annealing temperature, the phase transition from hexagonal to cubic occurs. Moreover, as it can be seen in Table 1, crystal size also increases by increasing the annealing temperatures. Grain size values were calculated using the following equations and listed in the Table 1.

Debye-Scherrer's formula

$D=\frac{k \lambda}{\beta(h k l) \cos \theta}$,

where $D$ is the crystal size, $k$ is the a constant whose value is approximately 0.9 and it is a shape factor, $\theta$ is the bragg angle, $\lambda$ is the wavelength of the $\mathrm{X}$-ray of $\mathrm{Cuk}_{\alpha}$, and $\beta$ is the width (in radians) of the peaks [16].

FESEM images of the CdS films before and after annealing at 300,400 , and $500{ }^{\circ} \mathrm{C}$ are shown in Fig. 2. All the films show a densely packed structure. It can be seen that by increasing the annealing temperature grain size increases, which can be explained as follows: grain size increases with annealing due to the sufficient temperature provided to move the grain boundaries. The grain growth mechanism can be considered to the GRIGC mechanism $[17,18]$. In this model, a neck would be shaped between the neighboring grains. After formation the neck, the two grains will grow along the preferred direction. This leads to the coalescence of neighboring grains via removing their common grain boundaries.

Figure 3a-d show 3D AFM images of the as-grown, annealed at 300,400 , and $500{ }^{\circ} \mathrm{C} \mathrm{CdS}$ thin films. The results show that increasing of the annealing temperature 
Table 1 Band gap, grain size, and roughness values for the asgrown, annealed at 300, 400, and $500{ }^{\circ} \mathrm{C} \mathrm{CdS}$ samples

\begin{tabular}{llllllll}
\hline Sample & $E_{\mathrm{g}}(\mathrm{eV})$ & $2 \theta($ Deg. $)$ & $h k l$ & $\beta($ radian$)$ & Grain size $(\mathrm{nm})$ & RMS $(\mathrm{nm})$ & $R_{\mathrm{a}}(\mathrm{nm})$ \\
\hline As-grown & 2.44 & 26.56 & 110 & 0.0040 & 35.47 & 3.96 & 3.36 \\
$300{ }^{\circ} \mathrm{C}$ & 2.38 & 26.5 & 110 & 0.0047 & 30.21 & 1.52 & 1.31 \\
$400{ }^{\circ} \mathrm{C}$ & 2.48 & 27.13 & 002 & 0.0034 & 40.76 & 3.44 & 2.73 \\
$500{ }^{\circ} \mathrm{C}$ & 2.31 & 27.14 & 002 & 0.0036 & 40.78 & 7.78 & 6.27 \\
\hline
\end{tabular}
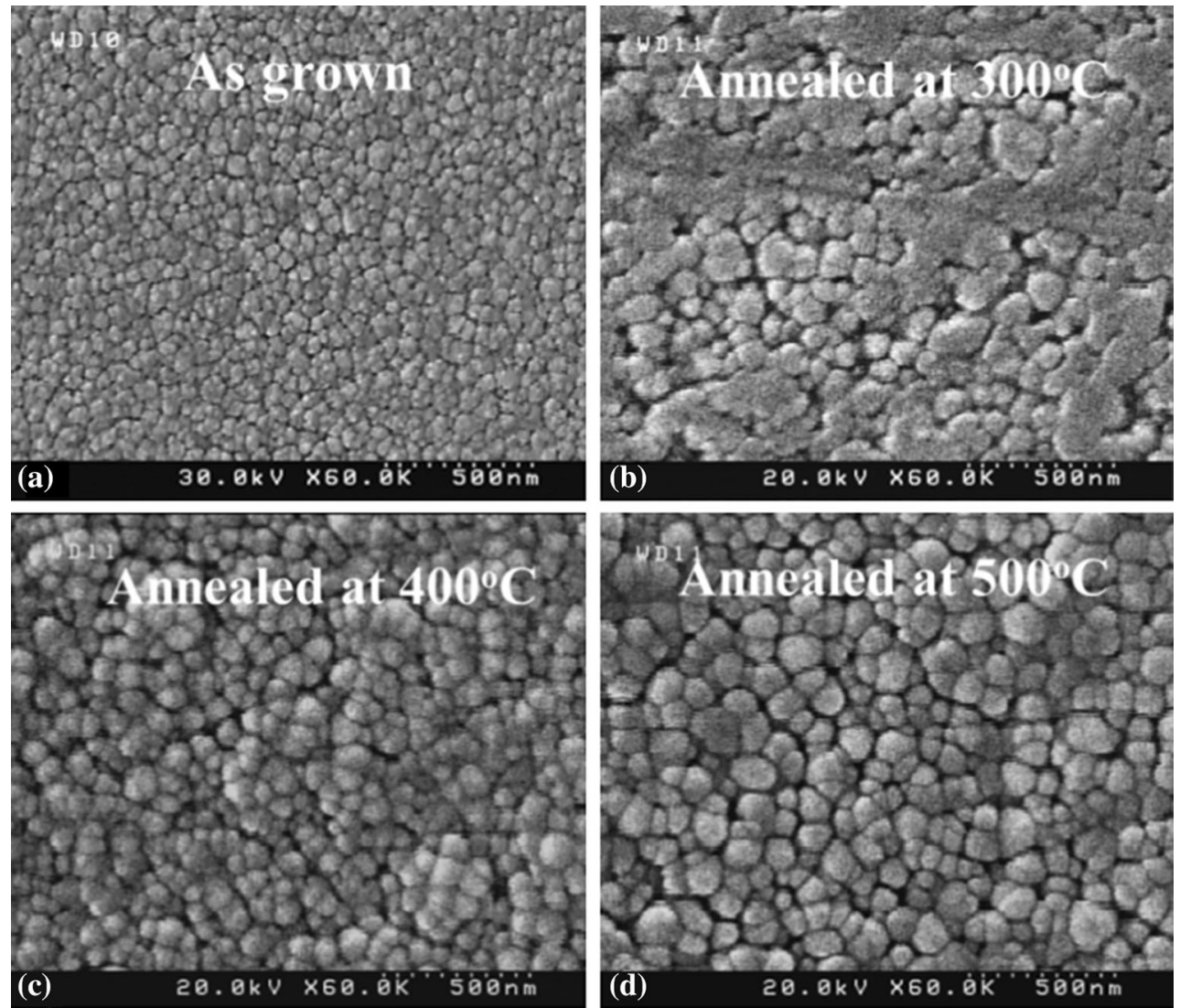

Fig. 2 FESEM micrographs of the a as-grown, b annealed at $300{ }^{\circ} \mathrm{C}$, $\mathbf{c}$ annealed at $400{ }^{\circ} \mathrm{C}$, and $\mathbf{d}$ annealed at $500{ }^{\circ} \mathrm{C}$ CdS samples

from 300 to $500{ }^{\circ} \mathrm{C}$ causes the increasing of the size of the grains. This is due to the increase in the mobility and the migration by increasing of annealing temperature. The RMS and average roughness of films obtained from AFM analysis (Fig. 3; columns $7 \& 8$ of Table 1) show a rough Surface for as deposited films. At $500{ }^{\circ} \mathrm{C}$ annealing temperature roughness reaches the maximum value. It is known that the increase of the surface roughness of window layer also decreases the reflective loss of solar cell and it is desired for the window layer because this phenomenon leading to an increase in the quantum efficiency of solar cell [19].

The transmission spectra of the CdS thin films deposited at room temperature and post annealed at 300, 400, and $500{ }^{\circ} \mathrm{C}$ in the wavelength range of $300-800 \mathrm{~nm}$ are illustrated in Fig. 4.
All the films display with the fringes at higher wavelengths of $500 \mathrm{~nm}$, which indicates the homogenous structure of deposited CdS layers. The absorption edges of the films have tolerance between 500 and $550 \mathrm{~nm}$ that refers to band gap value of the films. It can be observed that the transmittance of the films increased considerably with increasing the annealing temperature up to $500{ }^{\circ} \mathrm{C}$. The increment of transmittance from $40 \%$ to over $70 \%$ by post annealing treatment may caused by reduction in voids and lattice imperfections, increase in grain size which is in correlation with measured value of crystal size in Table 1 .

The optical band gap energy of the films was determined using the Tauc formula [20, 21]. Figure 5 shows the extrapolation of $(\alpha h v)^{2}$ versus $h v$ with the intercept of the straight line with the $h v$ axis which gives the band gap values. The existence of sub-band gap of $2.40-2.41 \mathrm{eV}$ at 


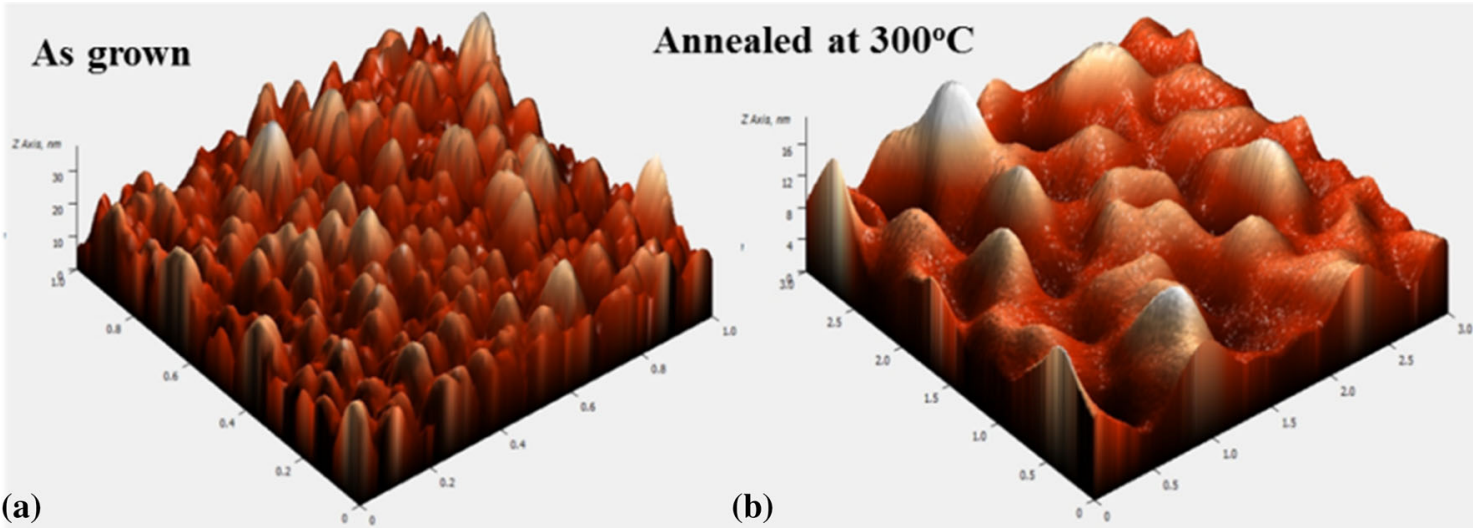

\section{Annealed at $400^{\circ} \mathrm{C}$}

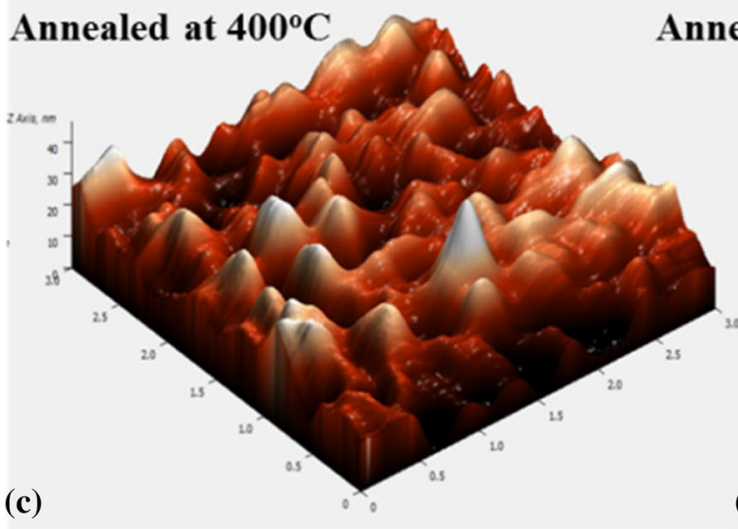

ealed at $500^{\circ} \mathrm{C}$

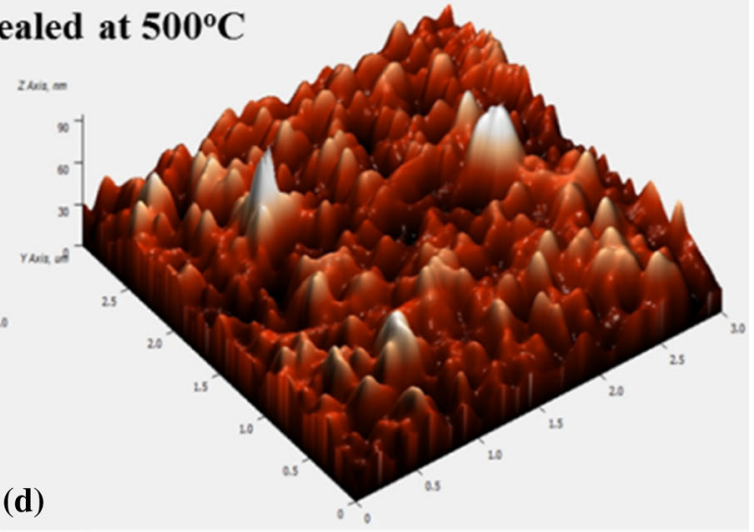

Fig. 3 AFM images of the a as-grown, b annealed at $300{ }^{\circ} \mathrm{C}$, $\mathbf{c}$ annealed at $400{ }^{\circ} \mathrm{C}$ and $\mathbf{d}$ annealed at $500{ }^{\circ} \mathrm{C} \mathrm{CdS}$ samples

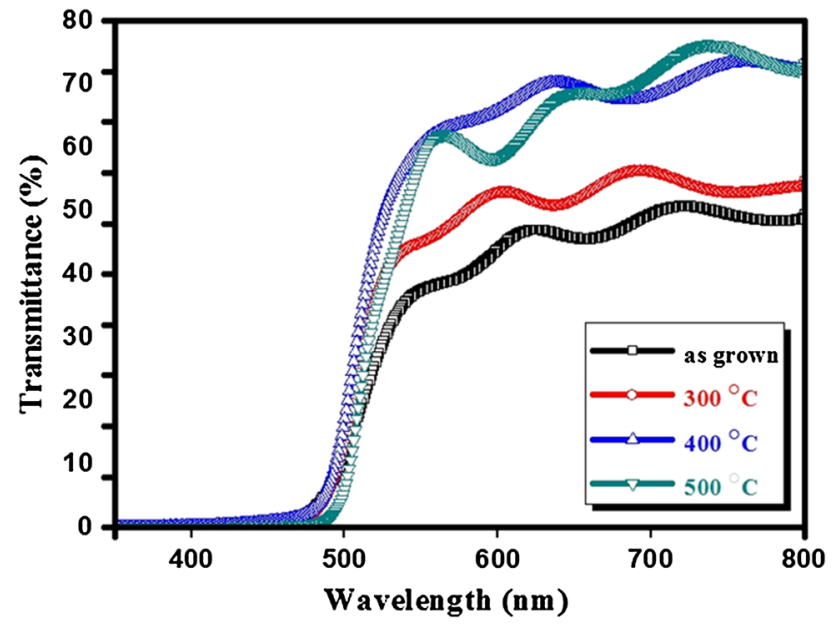

Fig. 4 Transmission as a function of wavelength for an as-grown (in black), annealed at $300{ }^{\circ} \mathrm{C}$ (in red), annealed at $400{ }^{\circ} \mathrm{C}$ (in blue) and annealed at $500{ }^{\circ} \mathrm{C}$ (in green) $\mathrm{CdS}$ samples

annealing temperature of 400 and $500{ }^{\circ} \mathrm{C}$ is noticeable which refers to cubic structure. Conversely, for the asgrown film and $300{ }^{\circ} \mathrm{C}$ annealing temperature, the subband gap disappeared. It could be observed from inset graph of Fig. 5 that the band gap value decreased from $2.44 \mathrm{eV}$ for as-grown film to $2.39 \mathrm{eV}$ for $300{ }^{\circ} \mathrm{C}$ annealed

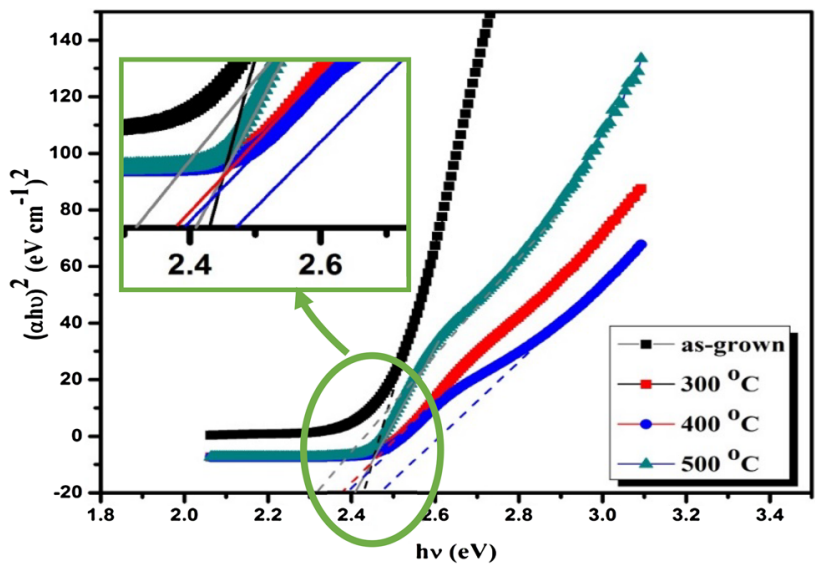

Fig. 5 Optical band gap calculation of the as-grown (in black), annealed at 300 (in red), 400 (in blue), and $500{ }^{\circ} \mathrm{C}$ (in green) $\mathrm{CdS}$ samples

sample, which could be due to the improvement in lattice structure [22]. The increment in band gap value to $2.48 \mathrm{eV}$ for $400{ }^{\circ} \mathrm{C}$ annealing temperature indicates phase transition in crystalline structure from hexagonal to the cubic phase, hence the lowest value of the optical band gap energy of $2.31 \mathrm{eV}$ achieved for sample annealed at $500{ }^{\circ} \mathrm{C}$. The calculated values for the band gap are given in Table 1. 


\section{Conclusion}

The RF magnetron sputtered CdS thin films are thermally annealing in air and the resultant film properties are studied in this work to improve the $\mathrm{CdS}$ thin film properties as a window layer in photovoltaic applications. XRD patterns indicate that the resulting films show polycrystalline structure with phase transition after annealing. It has been found that the CdS thermal annealing in air does not affect its band gap but the surface roughnesses and grain sizes of the films are observed to considerably increase after annealing, which may be the results of the grain boundary movement. Moreover, the transmittance of the films was increased up to $70 \%$ after annealing at $500{ }^{\circ} \mathrm{C}$. In summary, annealing the CdS can improve some of the physical properties that are advantageous for the solar cell applications.

Open Access This article is distributed under the terms of the Creative Commons Attribution 4.0 International License (http://crea tivecommons.org/licenses/by/4.0/), which permits unrestricted use, distribution, and reproduction in any medium, provided you give appropriate credit to the original author(s) and the source, provide a link to the Creative Commons license, and indicate if changes were made.

\section{References}

1. Amin, N., Sopian, K., Konagai, M.: Numerical modeling of CdS/ CdTe and CdS/CdTe/ZnTe solar cells as a function of CdTe thickness. Sol. Energy Mater. Sol. Cells 91, 1202-1208 (2007)

2. Wang, H.: Progress in Thin Film Solar Cells Based on $\mathrm{Cu}_{2-}$ $\mathrm{ZnSnS}_{4}$. Int. J. Photoenergy 2011, 801292 (2011). doi:10.1155/ 2011/801292

3. Ramanathan, K., Contreras, M.A., Perkins, C.L., Asher, S., Hasoon, F.S., Keane, J., Young, D., Romero, M., Metzger, W., Noufi, R., Ward, J., Duda, A.: Improved performance in $\mathrm{ZnO} /$ $\mathrm{CdS} / \mathrm{CuGaSe} 2$ Thin-film solar cells. Prog. Photovolt. Res. Appl. 11, 225-230 (2003)

4. Chu, L., Chu Shirley, A.: Thin film II-VI photovoltaics. Solid State Electron. 38(1), 533-549 (1995)

5. Nair, P.K., Campos, J., Nair, M.T.S.: Optoelectronics characteristics of chemically deposited cadmium sulphide thin films. Semicond. Sci. Technol. 3(2), 134-145 (1988)

6. Tomas, S.A., Vigil, O., Alvarado Gil, J.J., Lozada Morales, R., Zelaya Angel, O., Vargas, H., Ferreira da Silva, A.: Influence of thermal annealings in different atmospheres on the band-gap shift and resistivity of CdS thin films. J. Appl. Phys. 78(4), 2204-2207 (1995)
7. Han, J., Spanheimer, C., Haindl, G., Fu, G., Krishnakumar, V., Schaffner, J., Fan, C., Zhao, K., Klein, A., Jaegermann, W.: Optimized chemical bath deposited CdS layers for the improvement of CdTe solar cells. Sol. Energy Mater. Sol. Cells 95, 816-820 (2011)

8. Kim, H., Kim, D.: Influence of CdS heat treatment on the microstructure of CdS and the performance of CdS/CdTe solarcells. Sol. Energy Mater. Sol. Cells 67(1-4), 297-304 (2001)

9. Mahmoud, S.A., Ibrahim, A.A., Riad, A.S.: Physical properties of thermal coating $\mathrm{CdS}$ thin films using a modified evaporation source. Thin Solid Films 372, 144-148 (2000)

10. Enrique, J.P., Mathew, X.: Influence of the thickness on structural, optical and electrical properties of chemical bath deposited CdS thin films. Sol. Energy Mater. Sol. Cells 76, 313-322 (2003)

11. Sasikala, G., Dhanasekaran, R., Subramanian, C.: Electrodeposition and optical characterisation of CdS thin films on ITOcoated glass. Thin Solid Films 302, 71-76 (1997)

12. Pouzet, J., Bernede, J.C., Khellil, A., Essaidi, H., Benhida, S.: Preparation and characterization of tungsten diselenide thin films. Thin Solid Films 208, 252-259 (1992)

13. Dushkina, N.M., Ullrich, B., Sakai, H., Segawa, Y., Hibino, K., Eiju, T.: Reflection properties of oriented thin CdS films formed by laser ablation. Thin Solid Films 360, 222-228 (2000)

14. Ghorannevis, Z., Akbarnejad, E., Elahi, A.S., Ghoranneviss, M.: Application of RF magnetron sputtering for growth of AZO on glass substrate. J. Cryst. Growth 447, 62-66 (2016)

15. Akbarnejad, E., Ghorannevis, Z., Ghoranneviss, M., Hantehzadeh, M.R.: Low temperature preparation of cadmium sulfide thin films for solar cell application. J. Nanoelectron. Optoelectron. 10, 818-822 (2015)

16. Cullity, B.D.: Elements of X-ray diffraction. Addison-Wesley Pub. Co, Reading (1956)

17. Leite, E.R., Giraldi, T.R., Pontes, F.M., Longo, E.: Crystal growth in colloidal tin oxide nanocrystals induced by coalescence at room temperature. Appl. Phys. Lett. 83(8), 1566-1568 (2003)

18. Penn, R.L., Banfield, J.F.: Morphology development and crystal growth in nanocrystalline aggregates under hydrothermal conditions: Insights from titania. Geochim. Cosmochim. Acta 63(10), 1549-1557 (1999)

19. Islam, M. A., Haque, F., Rahman, K.S., Dhar, N., Hossain, M.S., Sulaiman, Y., Amin, N.: Effect of oxidation on structural, optical and electrical properties of CdS thin films grown by sputtering. Optik 126(21),3177-3180 (2015)

20. Islam, M.A., Hossain, M.S., Aliyu, M.M., Chelvanathan, P., Huda, Q., Karim, M.R., Sopian, K., Amin, N.: Comparison of structural and optical properties of CdS thin films grown by CSVT, CBD and sputtering techniques. Energy Proc. 33, 203-213 (2013)

21. Khallaf, H., Chen, C.T., Chang, L.B., Lupana, O., Dutta, A., Heinrich, H., Shenoud, A., Chow, L.: Chemical bath deposition of $\mathrm{SnO}_{2}$ and $\mathrm{Cd}_{2} \mathrm{SnO}_{4}$ thin films. Appl. Surf. Sci. 258, 6069-6074 (2012)

22. Wenyi, L., Xun, C., Qiulong, C., Zhibin, Z.: Influence of growth process on the structural, optical and electrical properties of CBD-CdS films. Mater. Lett. 59(1), 1-5 (2005) 